\title{
The revival of East Berlin's land market after the German reunification
}

\author{
Rainer Schulz and Martin Wersing*
}

February 7, 2018

${ }^{*}$ University of Aberdeen Business School, Edward Wright Building, Dunbar Street, Aberdeen AB24 3QY, United Kingdom. Emails: r.schulz@abdn.ac.uk (corresponding author) and martin.wersing@abdn.ac.uk. We are grateful for comments and suggestions by two anonymous referees, Paul Cheshire and Christian Hilber (the guest editors), Jens Kolbe, Euan Phimister, and Verity Watson. We thank Michaela Beeck, Brit Boche, and Gabriele Knopf from the Statistical Office Berlin-Brandenburg for their help with some of the data. The usual disclaimer applies. 


\begin{abstract}
The communist regime in the German Democratic Republic (GDR) curtailed property rights in the urban land market through expropriation, forced administration, rationing, and restrained marketability. After the fall of the Berlin Wall in 1989, well-defined property rights had to be reestablished to restore competitive urban land markets under German laws. We examine the revival process from 1990-2008 for East Berlin, the capital of the former GDR. West Berlin, which always had a market-based land market, is used as comparator. We find that the revival of the East Berlin land market and substantial investment support resulted in a swift convergence in the composition of the housing stock and in the pricing behavior in both parts of Berlin.
\end{abstract}

Keywords: property rights, urban land market, housing

JEL Classification: K25, P25, R31 


\section{Introduction}

After forty years in existence, the communist East German Democratic Republic (GDR) acceded on 3 October 1990 to the market-based West German Federal Republic of Germany (FRG). Most citizens of the GDR supported the accession, because the communist regime had failed economically and politically, whereas the FRG had a strong record of economic success, high living standards, and political stability (Frowein 1991). The German reunification brought the East German economy instantly a legal system with enforceable rules of contract. However, unambiguously assigned property rights were missing in East Germany because these had been purposefully destroyed by the communist regime. The assignment of such rights was essential for the transition into a market-based economy.

In this paper, we analyse the transition of East Berlin's land and housing market from 1990 until 2008. For the analysis, we use transaction data and information on the building stock. Data from West Berlin, which has always been part of the FRG, provides comparative evidence. We focus on three aspects. First, we examine if and how the chosen privatization method affected the speed of the transition process. Politicians decided that property transferred into state control between 1945-1948 should be sold, whereas property transferred during the GDR should be restituted in kind. ${ }^{1}$ The former related mainly to firms and agricultural land, whereas the latter related to urban land and residential property. Economists objected to this decision, because they anticipated that restitution would delay economic improvement

\footnotetext{
${ }^{1}$ The restitution provision was included in the unification treaty after the West German government exerted "massive pressure" on the East German government (Brücker 1997, p.127). For a categorization of privatization methods, see Roland (2000, Chapter 10).
} 
in East Germany and could cause social frictions in Germany (Möschel 1992, Sievert 1993, Sinn and Sinn 1993). Decisions on restitution claims take time and assignment of ownership rights can be complicated, for instance because roads or housing units were constructed on expropriated land. Restitution claims can also jeopardize valuable investment projects, for instance when the possessor of a plot cannot sell it to a housing developer due to an unsettled claim (Sinn and Sinn 1993, p.112). It is also debatable whether restituted owners or their heirs will make the best use of the property (Brücker 1997, pp.84). Second, we examine the total effect of the generous accelerated depreciation allowances, which complemented the privatization. The allowances were intended to extend and improve the housing stock in East Germany. The pre-war stock was mostly dilapidated and the stock constructed during the GDR was often inappropriate and located in decentralized settlements of tower blocks. In comparison with West Germany, only a small fraction of single-family houses was constructed during the communist regime; condominiums were nonexistent. The quality and composition of the stock needed to be improved to ensure social cohesion and facilitate labor mobility within the reunited Germany (Möschel 1992, p.492). Third, we analyze if by the end of our sample - nearly 20 years after accession - the land market in Berlin shows the relevant signs of an integrated market.

The results of our analysis are as follows. First, we find that the land market in East Berlin becomes active quite quickly. In the first years after the reunification, the transaction volume of land is above its long-run average and then converges to the same ratio of volume to long-run average that we observe for West Berlin. We take this as evidence that initially land in East Berlin was not efficiently allocated and that the revived market corrected this. We find that unusual legal characteristics, such as separate land and building 
ownership and complex restitution cases, delayed land transactions. Initially, single-family houses built during the communist regime had a low transaction propensity, because restitution was not conducive for merging the separate ownership of land and building. After a law introduced in 1994 provided clear procedures to merge the separate titles, the transaction propensity increased. This shows that restitution caused delays, as anticipated by economists. Second, we find that the accelerated depreciation allowances had a positive effect on housing construction. Soon after the reunification, housing construction begins in segments that were previously under-represented or non-existent. Persistently more single-family houses are constructed in East than in West Berlin. Multi-family buildings are converted into blocks of condominiums and new condominium buildings are constructed. Third, by the end of 2008, the Berlin housing market shows many signs of full integration. The housing stock has similar features in East and West Berlin. The growth of land and house prices has converged and the spatial distribution of land prices shows a smooth transition at the former border between East and West Berlin. Characteristics of single-family buildings are valued identically in East and West Berlin. Single-family houses in West Berlin are still more expensive on average, but this is due to nicer locations.

The rest of the paper is organized as follows. Section 2 discusses housing provision during the communist regime in East Germany. Section 3 discusses the problems that existed after the reunification for a revival of a marketbased land and housing market. It also discusses the main measures that were chosen by policy makers to deal with these problems. Section 4 examines empirically the revival of the land and housing market in East Berlin after the reunification. Section 5 concludes. The appendix provides details on the data and the empirical methods used in the analysis. 


\section{Land and housing under communism}

During its reign, the communist regime of the GDR aimed to bring as much property as possible under state control. While individuals could own property for personal use, such as a car or a single-family building, ownership of property as means of production of goods and services was all but impossible. To achieve this aim, the regime used expropriation, confiscation, and state administration. Procedural law was absent in the GDR and property owners could not contest decisions of state organs (Gesamtdeutsches Institut 1971, 1984).

Expropriation provisions are common in market-based countries and are used to assemble property for public projects, such as new roads and transport networks. However, the communist regime often implemented these provisions in a discriminatory way. For instance, West Germans received smaller financial compensation than GDR citizens for expropriated property in the GDR. The regime used provisions when no link to a public projects was given, solely to bring property under state control. Property of specific groups was confiscated, in particular the property of war criminals and perceived enemies of the socialist society. GDR citizens who fled the country had their property either confiscated and transferred into state ownership or placed under state administration. Property of foreigners was also placed under state administration. West Germans had the option to mandate a private administrator. Nevertheless, owners had no control rights over their property in the GDR once it was placed under administration.

The regime charged administrative fees for property of citizens who fled the GDR. These fees were punitively high, so that financial obligations soon exceeded the intentionally low assessed property values. In the liquidation 
process, the state could exploit its preemptive purchase right and acquire the property. The hostile treatment of small private enterprizes - the only form of private business allowed - resulted in the same outcome for many rental businesses. Rents were frozen at 1944 levels, tenants were allocated by state administrators, and rental income was taxed at a rate higher than employment income. Private landlords could be forced to take on loans on financially unfavorable terms. Landlords often forfeited their property to avoid liquidation. The regime also used extortion and coercion to acquire property, often for the personal benefit of regime officials. Permissions to leave the GDR were given to owners of single-family houses only after they forfeited the property, which was then placed under state administration and consigned to a state functionary. While formally illegal under GDR laws, such practices were executed frequently.

In the early years of the GDR, the transfer of private into state property had some legal pretense. In later years, this became less important. The regime and its officials treated most property as if it belonged to the state. For instance, single-family houses and land were allocated without regard for actual ownership. Confiscation and expropriation - even if executed following GDR legal procedures - and change of property ownership due to inheritance were seldom recorded (Vossius 1995, pp.4). Land registers were neglected, lost, or allowed to rot, see Horn (1994, p.224) and Sinn and Sinn (1993, p.115).

The impact of the communist regime on the ownership structure of the housing stock is visible from Table 1. It contains in Panel A data for East Berlin in 1990, one year after the end of the GDR. ${ }^{2}$ Compared with the data in Panel

\footnotetext{
${ }^{2}$ The 1995 building census for East Berlin retrospectively surveyed some few variables for 1990, amongst these was building ownership.
} 
B for the market-based West Berlin in 1987, ownership by natural persons is much lower in East Berlin, in particular in the multi-family sector. Whereas $53.4 \%$ of multi-family buildings in West Berlin are owned by natural persons, which includes ownership by condominium associations, only $9.9 \%$ are in East Berlin. The multi-family sector in East Berlin in 1990 is dominated by housing associations in state ownership, properties under state administration, and building cooperatives which could not choose members freely. This shows that the regime was effective in dismantling the private rental sector. In the single-family house sector, the difference is less pronounced, with $92.2 \%$ private owners in West and $80.2 \%$ in East Berlin. This provides evidence that the communist regime respected building ownership for personal use to some degree, although the $12.2 \%$ of single-family houses under state administration shows that this right could be taken away. ${ }^{3}$ Property rights of owner-occupiers were also curtailed in other respects. For instance, a sale was possible in principle, but required permission from state officials and could be conducted only at administered prices.

[Table 1 about here.]

The communist regime decided which existing buildings were worth maintaining, what new housing to build, and where to build it. The regime had no interest in maintaining the pre-1945 housing stock, in particular the working class districts in inner cities. Accordingly, the historical housing stock in city centers dilapidated over time. New housing construction focussed on large mass-produced tower blocks. This exploited economies of scale of standardization and prefabricated parts. Settlements of homogeneous blocks

\footnotetext{
${ }^{3}$ Some of the privately owned single-family houses could be rented out, but we presume that all are inhabited by their owners.
} 
were concentrated in the outskirts of cities. The dwellings in these blocks were small and of poor quality (Häußermann and Kapphan 2002, Strubelt 1996). GDR citizens could construct single-family houses for their own use on land assigned by the state, but completing such a project required a lot of personal initiative. ${ }^{4}$ The would-be building owner had to have access to goods that could be bartered for material and manual help. The necessary material was often unavailable and substitution with lower quality material was common.

The impact of the communist regime can be seen when we contrast the building and dwelling stock in East and West Berlin around the time of the reunification. Table 2 shows that buildings constructed before 1949 dominate the stock in East Berlin (1995), whereas most buildings in West Berlin (1987) are constructed after 1948..$^{5}$ The stock in East Berlin contains also fewer single-family houses. Nearly $80 \%$ of the multi-family buildings in East Berlin are damaged because of a lack of maintenance, half of them so severely that the functional safety is affected and fundamental repairs are required. Singlefamily buildings are in slightly better condition, but are also damaged because of the lack of maintenance and inappropriate building materials.

[Table 2 about here.]

Table 3 shows that the vintage distribution of dwellings in East and West Berlin is similar around the time of the reunification. In both parts of the

\footnotetext{
${ }^{4}$ Legally, only the building could be owned, whereas land was assigned by the state and remained in state ownership.

${ }^{5}$ The first building census for East Berlin was conducted in 1995; none was conducted for West Berlin. We use the 1987 census for West Berlin, which is closest to the reunification. This introduces a positive bias in favor of East Berlin and the true, but unobserved, differences are even more pronounced than discussed here.
} 
city, the majority of dwellings were constructed during the German division (1949-1990). As we observed above, only a few buildings were constructed during 1949-1990 in East Berlin, so that most of the dwellings are in massproduced large tower blocks which can have hundreds of units. Nearly $40 \%$ of all dwellings in East Berlin are in buildings in need of fundamental repairs, many of which are from the neglected pre-1949 stock.

[Table 3 about here.]

\section{Restitution and revival measures}

Given the unambiguous property rights and the poor condition of the housing stock at the end of the GDR, privatization and investment incentives were essential for any future economic improvement. The question of property rights was an integral part of the accession proceedings in 1990 (Heslop and Roberto 1993, III). It was decided and announced through the Joint Declaration from 15 June 1990 that formerly private property that was state-controlled in East Germany should be restituted in principle, and, where this was not possible, that expropriated former owners should be compensated financially or in-kind (the latter happened only occasionally). Compensation applied whenever the property was no longer available, because streets or multi-family housing were built on a-possibly cleared-plot. In the case of single-family houses, restitution was impossible if those in possession had obtained the property in good faith and followed the legal procedures of the GDR. Regime officials who obtained houses through coercion and deception could not retain them. Many members of the East German political and cultural elite were affected and lost possession of the buildings they occupied during the communist regime 
(Glock et al. 2001). Housing associations were transferred into municipal ownership and building cooperations transferred into the ownership of their members. Many of these housing providers encountered immediate financial difficulties. These occured because the providers had liabilities which were converted into Deutsche Mark, but were still bound by previously controlled rents. This made it difficult to finance the repairs that dilapidated buildings needed.

All restitution claims had to be filed by the end of 1992 . Once filed, the possessor of the contested property could take no actions, such as selling, signing new rental contracts or conducting repairs, until a decision on the claim was rendered (Stack 1997, p.1224). Decisions on claims were complicated, because entries in land registers could be missing or incomplete. Ownership histories could be fragmentary, way-leaves unclear, and information on a property's borders unknown. It was labor-intensive to complete the entries and this relied on documents pre-dating the GDR, such as archived land registers, past sales contracts, and old mortgage agreements. The incomplete documentation invited rent seekers to try their luck, even if their restitution claims were weak or unjustified. Consequently, it took months and often years to decide a restitution claim.

To ensure that only property with unambiguous rights comes to the market, the amended Land Transaction Act (Grundstücksverkehrsverordnung) stipulated that a property in East Germany needs a permission to be traded for the first time after the reunification. The permission is granted by the local land registry for properties with fully rectified entries and only if no undecided restitution claim is pending. Permissions can be obtained quickly for properties in successive private ownership by a family since before $1933 .{ }^{6}$

\footnotetext{
${ }^{6} \mathrm{At}$ the end of the GDR, $60.7 \%$ of all plots were still legally in private ownership
} 
Figure 1 shows the ratio of settled claims to all restitution claims for land and buildings in East Berlin. At the end of 1993, one year after the deadline for claims, $32.5 \%$ of claims had been settled by either restitution, financial compensation, release from state administration, or through the refusal of the claim. In 2000, about $95 \%$ of claims had been settled.

[Figure 1 about here.]

The economic recovery would have been slower if it had relied only on restitution. This became clear soon after the reunification and policy makers weakened the restitution principle by introducing the Investment Law in 1990, the Impediments Removal Law in 1991, and the Investment Priority Law in 1992. It became possible that those in possession could modify a property or that a property could be sold to an investor despite a pending restitution claim (Stack 1997, pp.1224). This required that the possessor or investor committed to investments which created jobs or improved the housing provision (Heslop and Roberto 1993, pp.260).

Single-family buildings constructed during the GDR on land assigned by the state initially remained legally separate. This was in conflict with German law, under which separate ownership of building and land is impossible. A grace period was agreed in the Joint declaration, so that building owners could retain the right of land use. But it was also announced that a future law would be enacted to regulate how the separate ownership rights should be merged. The legal uncertainty, however, made waiting a reasonable ac-

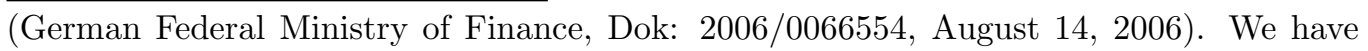
no detailed information on the specific situation in East Berlin. As not all property will have been traded for the first time since the reunification, the Land Transaction Act is still effective at the time of writing. 
tion. On 21 September 1994, the Property Adjustment Law (Sachenrechtsbereinigungsgesetz) was enacted to facilitate the merger of building and land ownership. The law presented building owners with the option to buy the land from the owner at half the assessed market value or to request a ground lease at similarly favorable terms (Vossius 1995).

The Assisted Area Law (Fördergebietsgesetz) was implemented in 1991 to encourage investment. This allowed generous accelerated depreciation opportunities for investments in East Germany and West Berlin. The law has been amended many times since. The intention of the law was to encourage the construction of new buildings. Later amendments favored investments that maintained the old building stock, and phased out incentives to invest in West Berlin (Töben 1996). The Liability Support Law (Altschuldenhilfegesetz) from 1993 reduced the cost of the liabilities of housing associations and building cooperatives under the condition that these organizations sell units in their multi-family building as condominiums, preferably to current tenants.

\section{Revival of East Berlin's land market}

We use transaction data of undeveloped land and of single-family houses to analyse the revival of the market in East Berlin after the reunification. We complement the transaction data with information on construction activity and other information on the Berlin economy. Appendix A.1 gives a detailed account of the different data sources. 


\subsection{Land market}

We look at the revival of the land market in East Berlin. First, we examine the volume of land transactions and the speed at which individual plots entered the market for the first time following the reunification. Second, we analyse the effect of the revived market activity on land prices in Berlin to examine if the market is integrated.

\subsubsection{Land transactions}

Figure 2 shows the volume of land (in sqm) transacted in West and East Berlin relative to its respective long-run average (left scale). ${ }^{7}$ In West Berlin, the ratio remains fairly stable after the reunification, albeit it settles at a slightly lower level than before the reunification. In East Berlin, the land market did not exist before the accession, but becomes active soon after. The relative transaction volume is particularly high during 1992-1996, which is the period during which the majority of restitution claims were decided, see Figure 1. The excess activity indicates that restituted properties were sold and not used by the former owners. ${ }^{8}$ Economists objected to restitution because it does not necessarily lead to an efficient initial allocation of property rights. Our results support this objection. Once this initial mismatch is corrected, the ratios for East and West Berlin behave very similarly.

[Figure 2 about here.]

\footnotetext{
${ }^{7}$ We do not observe the stock of developable land and take the long-run average as a proxy. Appendix A.2 gives details on the transaction data.

${ }^{8}$ Glock et al. (2001, pp.541) provide direct evidence and report for an area in Prenzlauer Berg, a district of East Berlin, that 58\% of properties restituted between 1991-1998 were sold on to third parties. In Kleinmachnow, a town close to Berlin, about $95 \%$ of restituted single-family houses were sold.
} 
We examine the factors which influence the speed at which plots of land in East Berlin are transacted for the first time after the reunification. To do so, we fit the regression

$$
\ln t_{i}=\alpha+\mathbf{x}_{i} \boldsymbol{\beta}+\mathbf{d}_{i} \gamma+\epsilon_{i}
$$

where $t_{i}$ is the number of days it takes from 3 October 1990 until plot $i$ is transacted. The row vector $\mathbf{x}_{i}$ contains different sets of variables that could affect how quickly plot $i$ is sold. The variables are binary indicators that take the value one if the characteristic is present and zero otherwise. The first set of variables describes legal characteristics of the transaction. Assembly indicates if the transaction joins two adjacent plots under legal joint ownership. Inheritance indicates if the transaction was part of an inheritance dispute. Contractual indicates if the transaction came with further contractual arrangements, such as investment commitments from the buyer. Merge indicates if the transaction unites building and plot ownership legally. The second set of variables controls for characteristics of the plot. Back indicates a plot that is located off the street and that access might be only possible through right of way over the - separate - front plot. Contamination indicates if a plot is contaminated or if contamination is likely. Heritage site indicates if the plot is a designated heritage site. Commercial use indicates if the plot is located in an area zoned for commercial and mixed residentialcommercial use. Waterfront indicates if the plot has direct access to a lake or river. The third set of variables control for the combination of sectors (private and public) the seller and the buyer belong to. We also include a full set of district dummies to control for local differences.

For the regression sample, we identify transacted plots on the basis of the street address and for each plot we select the first transaction. We have to ensure that we do not select follow-on transactions such as plots that 
were subdivided or assembled after the first transaction. In many cases we identify subdivisions and assemblies on the basis of the street address. In some cases a subdivision or assembly could have been accompanied by an address change. We would then, unknowingly, select repeated transactions for the sample. This problem becomes more prevalent the longer our sample period. We thus restrict our analysis to the period from 3 October 1990 and 31 December 1999, during which nearly 95\% of all restitution claims for property in East Berlin were decided.

Table 4 presents the estimated coefficients for Eq. 1, which are all statistically significant at the usual levels. ${ }^{9}$

[Table 4 about here.]

The effects of a plot's legal characteristics on the time taken until it is transacted for the first time are as follows. Plots involved in land assembly take on average $22.6 \%(\exp \{0.204\}-1)$ longer to be transacted than the average plot. Complicated restitution should not be the reason for this delay and we attribute it to the hold-out problem, in which the owner of the plot that should be assembled exerts market power over the interested buyer. Even if strategic hold-out were not relevant, land assembly in itself would be more time consuming in a market that is just reviving. Plots sold in connection with inheritance proceedings take on average $10.6 \%$ less time until the first transaction. There are two complementary explanations. First, such plots could have stayed in family ownership during the GDR and have unambiguous property rights. Restitution, if required, and a permission to trade would

\footnotetext{
${ }^{9}$ We estimated also a proportional hazard model and used a truncated maximum likelihood estimator, which corrects for the potential right-truncation of the sample. The qualitative results remain the same to those reported here.
} 
be easy to obtain. Second, heirs might agree to trade quickly, because they want to monetize the windfall profit from a property to which they have no emotional connection. This should reduce the transaction time even further. If a plot comes with special contractual arrangements, the expected time until the first transaction is $4.3 \%$ longer than average. Contractual arrangements relate in particular to investment commitments, which can override the restitution principle, see Section 3. Investors will use such arrangements when restitution claims are complex, therefore the estimated effect will understate the joint true cost of poorly assigned property rights and restitution. Transactions that merge legally building and land delay the expected time until the first sale of the plot by $30.9 \%$. Restitution of such plots should not be more complicated than for other plots, but before 1995, building and land could only be merged by private agreements between building and land owners. Such private agreements were presumably difficult to achieve.

Regarding the control variables, we find a delay for back plots. Such plots will only become attractive once the legal situation of the front plot is established and the rights of way recorded in the land register. This takes more time than establishing the property rights of the back plot itself, extending the expected time until the first transaction by $20.8 \%$. If the plot is contaminated, all else equal, potential buyers will require detailed inspections and cost assessments, which increase the expected time until the first transaction by $38.8 \%$. The development of plots that are designated as heritage assets are more time consuming and costly. This increases the expected time until the first transaction by $40.5 \%$. If the plot is located in an area that is zoned for commercial use, the expected time until the first transaction decreases by $65.4 \%$. These are mainly attractive inner-city plots in very good locations. If a plot is located on a waterfront, the expected time until the first transaction 
increases by $11.4 \%$. While these plots offer access to an attractive amenity, most of them are in less central locations. The last set of coefficients in Table 4 relates to seller and buyer combinations. The excluded category are sales in which both seller and buyer are from the private sector. This is the dominant category accounting for $90.9 \%$ of first-time land transactions. The coefficients show that the expected time until the first transaction is delayed once the public sector is involved. A plausible explanation is that the public sector was tasked after the reunification to ensure that the land market revives, whereas active intervention in the market was postponed to later years.

Table 4 provides evidence on the combined effect of ambiguous property rights inherited from the GDR and the privatization method chosen for the land market. Transaction delays are related to how property rights and properties were mistreated in the GDR. Contamination and the unclear legal situation of land and separate building ownership led to sizable delays. The effect of investment commitments also indicates that transactions were delayed by restitution.

\subsubsection{Land prices}

Figure 3 shows in its top-left panel box plots of the real land price (per sqm) for each year in 1980-2008. In all years in which land prices for Berlin are observed, the median price is higher in West than in East Berlin. This difference in levels is reasonable given the many attractive neighborhoods in West Berlin.

[Figure 3 about here.]

To examine the price growth once amenity differences are accounted for, we compute quality-controlled land price indices, for details see Appendix 
A.3. Figure 2 shows the growth rates for these indices (right axis). In the years immediately after the reunification, land prices show a strong growth in East Berlin, but growth soon converges to the rate in West Berlin. The convergence is a sign of an integrated land market, where land prices react similarly to systematic factors, such as shocks to the local economy.

We estimate land price gradients for East and West Berlin to examine if land prices show signs of integration at the spatial level. We do this for two time periods: $1991-1999$ and $2000-2008 .^{10}$ Figure 3 shows the estimated gradients along with point-wise confidence bands at the $95 \%$ significance level. We choose Potsdamer Platz as the central business district (CBD). This square was the heart of Berlin until the end of the Second World War, was cleared during the Cold War and separated by the Wall, and became the central building site after the reunification.

Land price gradients estimated with transactions from the 1991-1999 period (top-right panel) and the 2000-2008 period (bottom-left panel) decrease with the distance from the CBD in West and East Berlin. This is in accordance with the predictions of the Alonso-Muth monocentric city model. The gradients estimated for the 1991-1999 period are steeper than those for the 20002008 period. One possible explanation for this result is that prime inner-city plots were transacted first and that plots transacted in the 2000-2008 period were of lower quality. A second, complementary, explanation is that market participants paid prices during 1991-1999 based on the expectation that Berlin would become the economic powerhouse that it had been before the Second World War. ${ }^{11}$ This did not happen. When taking the estimation un-

\footnotetext{
${ }^{10}$ Land price gradients are estimated with semiparametric regressions that control for characteristics of the plot and the transaction, time effects and district fixed effects; Appendix A.4 provides details.

${ }^{11}$ The expectations were fueled by the decision of the German Parliament in 1991 for
} 
certainty into account, the land price levels at the CBD are not statistically different in West and East Berlin in each of the two periods. Focussing on the point estimates, this result is stronger for the second period (bottom-left panel). Land close to the CBD is priced very similarly in East and West Berlin, which is to be expected for an integrated land market, because plots are close to the same amenities. Once we move away from the CBD - from about $2.5 \mathrm{~km}$ onwards - the land price gradient for West Berlin lies above the gradient for East Berlin. The difference is statistically significant in most cases and reflects the many attractive neighborhoods in West Berlin.

The bottom-right panel of Figure 3 shows the land gradient for West Berlin estimated with transactions from 1980-1990. During this period, Potsdamer Platz was an empty space close to the Berlin Wall and land prices close to it were low. The effective CBD was around the Kurfürstendamm, where land prices are highest. The reunification opened up Potsdamer Platz as the CBD and the effect on land prices in West Berlin is visible in the bottom-left panel. Taking the evidence together, at the end of the sample period, land prices in East and West Berlin show behavior that is to be expected from an integrated market.

\subsection{Housing market}

The communist regime in the GDR focused on housing provision in massproduced tower blocks that contained standardized apartments and ignored the stock of pre-1949 buildings. The construction of single-family houses was a challenging endeavor and land provided had unclear property rights; Berlin becoming the capital of the reunited Germany and the hope that Berlin would host the 2000 Olympic Games. 
condominiums were nonexistent. The sale and purchase of existing singlefamily houses was tightly regulated. This resulted in a building stock that was ill-suited to the population's needs in terms of composition, ownership rights, and quality. Post-reunification, policy makers hoped that the market would improve the housing provision quickly. Policy makers encouraged this using tax and other incentives.

We examine the transition in the East Berlin housing market from three angles. First, we analyse the construction activity and look at the effects this had on the composition of the stock and the ownership structure. Second, we analyse the transaction activity in the single-family house market after the reunification and assess the effect of the Property Adjustment Law, which was introduced in 1994 to merge building and land ownership. Third, we analyse the behavior of house prices and examine whether implicit prices of building characteristics converge between East and West Berlin.

\subsubsection{Construction activity}

After the reunification, market-based building construction started in East Berlin. This activity was encouraged by tax incentives, see Section 3. Figure 4 shows in its left panel the number of dwellings constructed between 19912008 in single-family (left axis) and multi-family buildings (right axis).

[Figure 4 about here.]

While the number of completed dwellings in single-family houses remained fairly stable in West Berlin, many more dwellings were completed in East Berlin. With exception of the period 1996-1998, completions of dwellings in multi-family buildings followed a similar trend in East and West Berlin. The 
difference in the number of completions between 1996 and 1998 is most likely the result of accelerated depreciation allowances, which were extended for East, but not West Berlin. In addition to the construction of new buildings, amendments of the Assisted Area Law in 1993 encouraged the repair and modernization of pre-1990 buildings. For some buildings, this was not economically feasible, because the buildings were either damaged beyond repair or dwellings were not in demand and vacant. The latter applied in particular to dwellings in blocks constructed during the GDR. By 2007, blocks with a total of 2,485 dwellings had been demolished in East Berlin (Bundesministerium für Verkehr, Bau und Stadtentwicklung 2007).

The implementation of German law in East Germany implied condominium ownership in multi-family buildings became possible. The right panel of Figure 4 shows the number of conversions of rental units (left axis) and the number of condominiums in newly constructed buildings (right axis) between 1991-2008. Conversions of rental apartments into condominiums show a very similar trend in East and West Berlin. In East Berlin, conversions began in 1993, but we see no further evidence that the Liability Support Law hadcompared with the trend in West Berlin - a strong effect.

Table 2 shows the effect of construction, demolition, and conversion on the composition of the housing stock in East Berlin. In 2011, buildings are, on average, younger in East than in West Berlin. The share of pre-1949 buildings is about the same, but buildings constructed since the reunification contribute $32.6 \%$ to the stock in East and only $10.6 \%$ in West Berlin. Singlefamily houses are the dominant building type in East Berlin in 2011, as it is the case for West Berlin. With respect to dwellings, Table 3 shows that more dwellings in East Berlin are in buildings constructed after 1995 than in West Berlin, but that less dwellings are in buildings constructed before 
1949. Despite these small differences, the vintage distribution of dwellings in 2011 is very similar in East and West Berlin. This implies that housing built during the communist regime is still very important in $2011.47 .0 \%$ of all dwellings in East Berlin in 2011 are in the large blocks and other buildings constructed during the GDR.

Table 1 shows how building ownership has changed in East Berlin since 1990. In 2011, single-family houses in East Berlin are owned nearly exclusively by natural persons, which is identical to the situation in West Berlin in 1987 and 2011. The large majority of such houses is occupied by owners (East Berlin $88.7 \%$ and West Berlin 77.9\%). Natural persons' ownership of multi-family houses is $39.1 \%$ in East Berlin in 2011, less than the $54.9 \%$ in West Berlin, but a large increase from the $9.9 \%$ in 1990. Back then, most multi-family buildings were under state control in East Berlin. After the reunification, the buildings were transferred into the ownership of housing associations, privatized, or demolished. The last column in Table 1 shows that the ownership structure is in 2011 very similar in East and West Berlin.

\subsubsection{House transactions}

Figure 5 shows the relative transaction volume of single-family houses (left scale). In East Berlin, transactions revived quickly after the reunification. By 2000, the transactions relative to the stock in East and West Berlin are very similar and move together, as one would expect for an integrated housing market.

[Figure 5 about here.]

In the GDR, single-family buildings could be constructed on land allocated by the state. This implied that after the reunification, land and building 
could be legally separate units, which conflicted with German law. We have seen above that this impeded the liquidity of affected plots. In 1994 the Property Adjustment Law was enacted to facilitate the legal merging of land and building. We analyse whether this law increased the transaction propensity of houses constructed in East Berlin during the communist regime, relative to houses that were constructed during the same period in West Berlin and relative to houses constructed in both parts of Berlin before 1949. For the analysis, we use all house transactions since 1990 and fit the probit regression

$$
P\left(y_{i}=1 \mid D_{i}^{E}, D_{i}^{A}, \mathbf{x}_{i}\right)=\Phi\left(\beta_{1} D_{i}^{E}+\beta_{2} D_{i}^{E} \times D_{i}^{A}+\mathbf{x}_{i} \gamma\right) .
$$

The binary dependent variable $y_{i}$ takes the value one if house $i$ has been constructed during the period 1949-1989, and is zero otherwise. $D_{i}^{E}$ is a binary indicator that takes the value one if house $i$ is located in East Berlin and the value zero otherwise. $D_{i}^{A}$ is a binary indicator that takes the value one if house $i$ is transacted after the Property Adjustment Law became enacted. The coefficient $\beta_{2}$ for the interaction term $D_{i}^{E} \times D_{i}^{A}$ measures the impact of the law on the transaction propensity of houses constructed during the communist regime. The row vector $\mathbf{x}_{i}$ contains control variables. These are the floor to area ratio of the house and binary indicators that take the value one if the characteristic is present and the value zero otherwise. Attic indicates if the attic is upgraded for living. Flat roof indicates if the house has a flat roof. 2-3 storeys indicates if the house has more than one storey. Waterfront indicates if the house has direct access to a lake or river. Building type considers four types, detached house is the excluded category. State of repair has three categories, a fair state of repair is the excluded category. Non-private indicates if either the seller or the buyer of the house is from the public sector. We also include a full set of yearly time dummies and district dummies in $\mathbf{x}_{i}$ which control for year and location effects. 
Table 5 presents maximum likelihood (ML) estimates of the marginal effects from Eq. 2. In column (1), we report a baseline specification that only includes the treatment indicator, as well as time-dummies and districtdummies. Column (2) adds the control variables to consider other factors that can impact on the transaction propensity.

[Table 5 about here.]

In both specifications, we find that single-family houses constructed during the communist regime have a significantly lower baseline propensity of being transacted than other such houses. The estimate in Specification (1) indicates that the propensity falls by $86.5 \%$ if the house was built in the GDR. Specification (2) takes the control variables into account, but the estimated marginal effect still indicates a fall of the propensity by $69.0 \%$. This result reflects to some degree that such houses represent only a small fraction of Berlin's single-family house stock. The estimated marginal effect of the interaction term is of more interest. The effect is statistically positive and economically significant. In Specification (2), the transaction propensity of a single-family house built in the GDR is 11.3 percentage points higher after the enactment of the Property Adjustment Law. This indicates that the Property Adjustment Law had the desired effect. The law facilitated the legal merger of ownership of buildings built in the GDR and the land they were residing, as is required under German law. This implied that the marketability of single-family houses increased and so did their transaction propensity.

\subsubsection{House prices}

The left panel of Figure 6 shows box plots for real single-family house prices for each year in the period 1980-2008. 
[Figure 6 about here.]

In all years since 1990, the median house price is lower in East than in West Berlin. This is to be expected, given the many attractive single-family house neighborhoods in West Berlin. While this difference in single-family house prices in East and West Berlin persists over the whole sample, the price growth rates converge. Figure 5 shows the price growth rates in East and West Berlin computed from quality-controlled indices (right axis). The rates converge soon after the reunification and follow the same pattern afterwards.

Figure 6 shows also the distribution of real building values, which are the house price minus the assessed value for the land (right-panel). ${ }^{12}$ Both values are less dispersed in East than in West Berlin. Building values-house prices controlled for location effects - vary because buildings represent bundles of characteristics and these characteristics are assessed at implicit price. Building values in an integrated market will differ whenever building characteristics differ (see Appendix A.2), but they should not differ because the characteristics are assessed with differential implicit prices.

We analyse this question for the Berlin market and apply the decomposition pioneered by Oaxaca (1973) and Blinder (1973). The dependent variable of our regressions is the logarithm of the building value, which implies that we effectively compare the median building value differential. Appendix A.5 gives details on the regression model.

Given the estimated regression function, the building value differential can

\footnotetext{
${ }^{12}$ The land values come from the provider of the transaction data. It is not uncommon in the literature to decompose the house price additively into the location (land) and the building value, see for example Rosenthal (1999) and Bourassa et al. (2011).
} 
be decomposed in

$$
D=\left(\overline{\mathbf{x}}_{W}-\overline{\mathbf{x}}_{E}\right) \widehat{\boldsymbol{\theta}}_{W}-\overline{\mathbf{x}}_{E}\left(\widehat{\boldsymbol{\theta}}_{W}-\widehat{\boldsymbol{\theta}}_{E}\right)
$$

where $\overline{\mathbf{x}}_{j}$ collects the average building characteristics in East $(j=E)$ and West $(j=W)$ Berlin, respectively. $\widehat{\boldsymbol{\theta}}_{j}$ are estimates of the respective coefficients. The first summand on the right hand side of Eq. 3 quantifies how much of the log building value differential can be attributed to differences in observed building characteristics. The second summand attributes the remainder of the differential to differences in the estimated coefficientsthe implicit prices - for these building characteristics including the constant term. For an integrated market, we expect that the building value differential is solely attributable to characteristic differences.

Table 6 summarizes the decomposition results. Given that the previously presented evidence suggests that both the land market and the housing market in East Berlin has been fully revived by 2000 , we split the sample of transacted single-family houses into the two subperiods 1991-1999 and 2000-2008.

[Table 6 about here.]

For the period 1991-1999, the average log building value differential is both statistically and economically significant. The exponentiated differential amounts to about 60,000 Euros, which implies that the median building value for single-family houses in West Berlin is $87 \%$ higher than in East Berlin. The decomposition of this building value differential reveals that it can be attributed to differences in both building characteristics and implicit prices for these characteristics. The former accounts for about $63 \%$ of the differential and the latter for about 37\%. The differential pricing provides evidence 
that the single-family house markets in East and West Berlin were not fully integrated.

For the period 2000-2008, the exponentiated building value differential between East and West Berlin is still statistically significant, but has decreased to EUR 10,000 (9.9\% of the median building value in West Berlin). Moreover, the total differential is solely attributable to the differences in building characteristics across East and West Berlin. The contribution of differences in the implicit prices for the building characteristics is not statistically significantly different from zero. While differences in building characteristics persist between East and West, the implicit prices for these characteristics are no longer different. This provides strong evidence for an integrated single-family house market in Berlin.

\section{Conclusion}

Urban land and housing markets can only function when property rights are well-defined and mechanisms exist to enforce contracts. Between 1949-1989, both conditions were fulfilled for West Berlin as part of the market-based FRG, but not for East Berlin, the capital of the communist GDR. Following the German reunification in 1990, the legal institutions of the FRG became effective in East Germany, which brought rules of contract and a juridical system to enforce them. To establish well-defined property rights, property under state control had to be privatized. Politicians decided for the principle of restitution, rather the alternatives of privatization to insiders, such as long-term tenants and building users, or sales to investors. ${ }^{13}$

\footnotetext{
${ }^{13}$ The latter two methods were also used in exceptional cases.
} 
Our paper shows that the land market in East Berlin revived quickly, but we also find evidence that the complex legal nature of restitutions caused delays. We find evidence that restitution meant that land was not immediately allocated to those most willing and able to use it. The revival of the land market is accompanied by an increase in housing construction, encouraged by generous tax depreciation allowances. This construction activity resulted in building and dwelling stocks with similar composition in the two parts of Berlin. Land and house prices growth converged soon after the reunification in East and West Berlin. Towards the end of our sample period, land prices have a spatial distribution in line with the monocentric city model and building characteristics are valued identically in both parts of Berlin. These are all signs of an integrated market.

Our results from the land and housing market of Berlin have general relevance for two reasons. First, our analysis helps to understand urban land markets in Germany. The revival of the land market in East Berlin might have been faster than elsewhere, because it could benefit from West Berlin's well-functioning administration. But absent possible differences in speed, the revival process should have been similar in other East German cities. This is an area for further investigation. Second, our results in the context of a particular land market show that transition is a lengthy process and exposed to many vagaries. East Germany was in a very favorable situation compared with other transition countries (Dornbusch and Wolf 1992, p.236). The reunification brought a functioning political and legal system, financial transfers, and, at least in the beginning, the wide backing of the transition by the East German population. However, the transition was not without frictions. Restitution, in addition to delaying transactions, also caused contention be- 
tween East and West Germans. ${ }^{14}$ Such frictions could have been avoided if the legal situation of users, such as single-family building owners, had been clarified sooner after the reunification. The same applies to the situation of tenants in state controlled multi-family buildings, who could have participated in the privatization process through purchase opportunities earlier. Other transition economies did not have the same resources available and in these circumstances market transition should be slower, remain unfinished, or could even reverse through the lack of political support (Rapaczynski 1996).

\section{A Appendix}

\section{A.1 Data sources}

Construction activity and building permits: The data comes from various reports provided by the Federal Statistical Office and the Statistical Office of Berlin-Brandenburg. The data covers the period 1991-2008.

Conversion of rental apartments to condominiums: The data comes from annual reports (Grundstücksmarktreport) published by Berlin's Committee of Valuation Experts (Gutachterausschuss für Grundstückswerte, GAA).

Digital map: The data comes from Berlin's Senate Department for Urban Development and Housing.

\footnotetext{
${ }^{14}$ The article 'Die Lage ist trostlos' in the weekly magazine Der Spiegel, 41/1990, gives several examples of former owners who tried to force single-family house users in East Germany out of the property.
} 
Housing stock: The data comes from the building censuses 1987, 1995 and 2011. The 1987 census is exclusively for West Berlin. The 1995 census is exclusively for East Berlin. For both censuses micro-data on the block level is provided by the Statistical Office of Berlin-Brandenburg. Additional information is taken from Statistisches Landesamt Berlin (1991) and Statistisches Landesamt Berlin (1997). Data from the 2011 census is compiled from the online census database of the Federal Statistical Office. This data is for the whole of Berlin. Further information used to disaggregate the data for East and West Berlin comes from Statistische Ämter des Bundes und der Länder (2014). The building census also provides information about owneroccupation rates.

Land and single-family house transactions: The data comes from Berlin's Committee of Valuation Experts (Gutachterausschuss für Grundstückswerte, GAA) and consists of all transactions of single-family houses and undeveloped land plots between 1980-2008. Prior to 3 October 1990, observations are exclusively for West Berlin. Nominal prices are deflated into real prices with the consumer price index (CPI) for Berlin. The CPI has the base year 2010 and is provided by Statistical Office of Berlin-Brandenburg.

\section{A.2 Description of transaction data}

Transaction activity: Table A1 shows the number of transactions-for both undeveloped land plots and single-family houses - per year.

[Table A1 about here.]

The number of transactions of land plots indicates that trading activity revived in East Berlin fairly quickly after the reunification. From 1993 onward, 
the number of transacted land plots is between three to four times higher in East than in West Berlin. The number of transactions of single-family houses in East Berlin also increased quickly after the reunification. The smaller stock means that the total number of transactions in East Berlin is always lower than in West Berlin.

Figure A1 shows the locations of land plots transacted in East Berlin (19902008) and West Berlin (1980-2008). The plots come from all the neighborhoods of East and West Berlin.

[Figure A1 about here.]

Most strikingly, there are a substantial number of transactions of land plots in central inner-city locations. This allows us to estimate land price gradients for the city as a whole. The transactions of single-family houses, on the other hand, are spatially concentrated in the suburban neighborhoods of East and West Berlin (not reported).

Single-family house characteristics: Table A2 summarizes the building type composition and the state of repair for the transacted houses in East and West Berlin.

[Table A2 about here.]

The first panel shows that the building type composition of the transacted houses becomes more similar in East and West Berlin over time. In the period 1991-1999, there are fewer terraced buildings and more detached buildings in East compared to West Berlin. However, by the period 2000-2008, new 
construction and also demolition in East Berlin mean that building composition is very similar across East and West Berlin. Similarly, the state of repair of buildings transacted in East Berlin improves over time, see Table A2. In the period 2000-2008, many of the transacted houses in East Berlin are in excellent condition, more than there are in West Berlin. Still, 16.4\% are in poor condition in East Berlin, whereas only $2.0 \%$ are in West Berlin.

Figure A2 shows box plots of the building vintages for the single-family houses transacted during the period 1980-2008.

[Figure A2 about here.]

Over time, the transacted houses in East Berlin become younger. Figure A3 shows box plots of the floor-to-area ratio (FAR).

[Figure A3 about here.]

The median FAR of houses transacted in East Berlin is, in each year except of 2003, smaller than in West Berlin. The median is also more variable in East than in West Berlin. Taken together, there are persistent differences in average building characteristics across both parts and substantial variation in building characteristics within each part of Berlin.

\section{A.3 Land and house price indices}

To compute constant-quality price indices, we use the regression

$$
\ln p_{i}=\mathbf{t}_{i} \gamma+\mathbf{e}_{i} \boldsymbol{\delta}+\mathbf{x}_{i} \boldsymbol{\beta}+\varepsilon_{i}
$$

where $p_{i}$ is the real price per sqm of plot $i$ (the real price of house $i$ ), the vector $\mathbf{t}_{i}$ contains a full set of yearly time dummies which are allowed to 
differ by East and West Berlin. This is achieved by including interaction terms between the time dummies and a East Berlin dummy in the vector $\mathbf{e}_{i}$. The vector $\mathbf{x}_{i}$ contains characteristics of the plot (house). In the land price regressions, $\mathbf{x}_{i}$ contains binary indicators for contaminated plots, plots located off the street, waterfront plots, heritage assets, further contractual arrangements, and type of buyer and seller. In the house price regressions, $\mathbf{x}_{i}$ contains binary indicators for the type of building, type of roof, state of repair, located at the waterfront, type of buyer and seller, and third-degree polynomials in the lot size, the floor size of the building, and the age of the building. The last polynomial is allowed to differ by a building's state of repair, which is achieved by including the respective interaction terms in $\mathbf{x}_{i}$. In both the land and house price regressions, we also include a third-degree polynomial in the distance to the CBD and a full set of district dummies in $\mathbf{x}_{i}$ in order to control for location-specific amenities. The constant-quality land and house price indices are then computed from the estimated time dummy coefficients and interaction terms in Eq. A1.

\section{A.4 Semiparametric land price regression}

To estimate the land price gradient, we use the semiparametric regression

$$
p_{i}=\mathbf{x}_{i} \boldsymbol{\beta}+m\left(d_{i}\right)+\varepsilon_{i}
$$

where $p_{i}$ is the real price per sqm of plot $i$, the vector $\mathbf{x}_{i}$ collects binary indicators for contaminated plots, plots located off the street, waterfront plots, heritage assets, further contractual arrangements, and type of buyer and seller. We also include a full set of district dummies and yearly time dummies in $\mathbf{x}_{i}$. The former control for location-specific amenities at the same distance to the CBD; the latter control for deviations of the general 
trend in land prices from the CPI. The land price gradient is modeled by $m\left(d_{i}\right)$, which is a smooth function in the distance of plot $i$ to the CBD. We estimate the coefficients in Eq. A2 using the difference estimator of Yatchew (2003, Chapter 4.5). The coefficient estimates are then used to compute $\tilde{p}_{i}=p_{i}-\tilde{\mathbf{x}} \widehat{\boldsymbol{\beta}}$. The control variables in $\tilde{\mathbf{x}}$ are set to represent a standard plot in the year 2000. We then estimate the land rent gradient nonparametrically by fitting $\tilde{p}_{i}$ to $d_{i}$ via a third-degree local polynomial kernel regressions. The bandwidth is chosen according to rule of thumb described in Fan and Gijbels (1996, Chapter 4.2).

\section{A.5 Building value regression}

To implement the building value decomposition we use the regression

$$
\ln b_{i}=\mathbf{s}_{i} \gamma+\mathbf{a}_{i} \boldsymbol{\delta}+\mathbf{r}_{i} \boldsymbol{\lambda}+\mathbf{x}_{i} \boldsymbol{\beta}+\varepsilon_{i}
$$

where $b_{i}$ is the real building value of house $i$, the vector $\mathbf{s}_{i}$ contains a thirddegree polynomial in the floor size of the building, and the vector $\mathbf{a}_{i}$ contains a third-degree polynomial in the age of the building. The latter polynomial is allowed to differ by the state-of-repair of the building, which is achieved by including the respective interaction terms in the vector $\mathbf{r}_{i}$. The vector $\mathbf{x}_{i}$ collects binary indicators for the type of building, type of roof, and type of buyer and seller. To control for deviations of the general trend in building values from the CPI we include also a full set of yearly time-dummies in $\mathbf{x}_{i}$.

We note that we use the building value - and not the house price - as dependent variable in the decomposition exercise. The house price would work as dependent variable if we observed all variables that are relevant for the explanation of location values. If we do not, as we suspect, a clean decomposition of the house price into building and location value is impossible and 
the estimated implicit prices for building characteristics would be conflated by uncontrolled amenity differences (Fortin et al. 2011).

\section{References}

Blinder, A. S.: 1973, Age discrimination: Reduced form and structural estimates, Journal of Human Resources 8, 436-455.

Bourassa, S. C., Hoesli, M., Scognamiglio, D. and Zhang, S.: 2011, Land leverage and house prices, Regional Science and Urban Economics 41, 134144 .

Brücker, H.: 1997, Privatization in Eastern Germany. A neo-institutional analysis, Frank Cass \& Co, London.

Bundesministerium für Verkehr, Bau und Stadtentwicklung: 2007, 5 Jahre Stadtumbau Ost, eine Zwischenbilanz. Zweiter Statusbericht der Bundestransferstelle, Leibniz-Institut für Regionalentwicklung und Strukturplannung, Erkner.

Dornbusch, R. and Wolf, H.: 1992, Economic transition in Eastern Germany, Brookings Papers on Economic Activity 1992(1), 235-272.

Fan, J. and Gijbels, I.: 1996, Local Polynomial Modelling and Its Applications, Chapman and Hall, London.

Fortin, N., Lemieux, T. and Firpo, S.: 2011, Decomposition methods in economics, in O. Ashenfelter and D. Card (eds), Handbook of Labor Economics 4A, Elsevier North-Holland, Amsterdam, pp. 1-102. 
Frowein, J. A.: 1991, Germany reunited, Zeitschrift für ausländisches und öffentliches Recht 51, 333-348.

Gesamtdeutsches Institut: 1971, Bestimmungen der DDR zu Eigentumsfragen und Enteignungen. Ausgabe August 1971, Bundesanstalt für Gesamtdeutsche Aufgaben, Bonn.

Gesamtdeutsches Institut: 1984, Bestimmungen der DDR zu Eigentumsfragen und Enteignungen. Ausgabe Mai 1984, Bundesanstalt für Gesamtdeutsche Aufgaben, Bonn.

Glock, B., Häußermann, H. and Keller, C.: 2001, Die sozialen Konsequenzen der Restitution von Grundeigentum in Deutschland und Polen, Berliner Journal für Soziologie 11, 533-550.

Häußermann, H. and Kapphan, A.: 2002, Berlin: Von der geteilten zur gespaltenen Stadt? Sozialräumlicher Wandel seit 1990, second edn, Leske + Budrich, Opladen.

Heslop, J. and Roberto, J.: 1993, Property rights in the reunified Germany: A constitutional, comparative, and international analysis, Boston University International Law Journal 11, 243-298.

Horn, N.: 1994, Die Rolle des Zivilrechts im Prozeß der Wiedervereinigung Deutschlands, Archiv für die civilistische Praxis 194, 177-230.

Möschel, W.: 1992, Strukturwandel in den fünf neuen Bundesländern - Eine Zwischenbilanz, JuristenZeitung 47(10), 489-493.

Oaxaca, R.: 1973, Male-female wage differentials in urban labor markets, International Economic Review 14, 693-709. 
Oaxaca, R. L. and Ransom, M.: 1998, Calculations of approximate variances for wage decomposition differentials, Journal of Economic and Social Measurement 24, 55-61.

Rapaczynski, A.: 1996, The role of the state and the market in establishing property rights, Journal of Economic Perspectives 10(2), 87-103.

Roland, G.: 2000, Transition and economics. Politics, markets, and firms, MIT Press, Cambridge MA.

Rosenthal, S. S.: 1999, Residential buildings and the cost of construction: New evidence on the efficiency of the housing market, Review of Economics and Statistics 81, 288-302.

Sievert, O.: 1993, Probleme des Übergangs vom Sozialismus zur Marktwirtschaft - Die Eigentumsfrage, in W. Dichmann and G. Fels (eds), Gesellschaftliche und ökonomische Funktionen des Privateigentums, Deutscher Instituts-Verlag, Köln, pp. 206-242.

Sinn, G. and Sinn, H.-W.: 1993, Kaltstart: Volkswirtschaftliche Aspekte der deutschen Vereinigung, Beck-Wirtschaftsberater im dtv, München.

Stack, H. M.: 1997, The "colonization" of East Germany?: A comparative analysis of German privatization, Duke Law Journal 46, 1211-1253.

Statistische Ämter des Bundes und der Länder: 2014, Gebäude und Wohnungen in den neuen Bundesländern und Berlin-Ost: Vergleich der Ergebnisse der Gebäude- und Wohnungszählungen 2011 und 1995. Accessed on January 30, 2017.

URL: www.statistikportal.de/Statistik-Portal/Zensus_2011_Vergleich.pdf 
Statistisches Landesamt Berlin: 1991, Gebäude- und Wohnungszählung in Berlin-West am 25. Mai 1987, Kulturbuch-Verlag, Berlin.

Statistisches Landesamt Berlin: 1997, Gebäude- und Wohnungszählung in Berlin-Ost am 30. September 1995, Kulturbuch-Verlag, Berlin.

Strubelt, W.: 1996, Regionale Disparitäten zwischen Wandel und Persistenz, in W. Strubelt, J. Genosko, H. Bertram, J. Friedrichs, P. Gans, H. Häußermann, U. Herlyn and H. Sahner (eds), Städte und Regionen - Räumliche Folgen des Transformationsprozesses, Leske + Budrich, Opladen, pp. 11-110.

Töben, T.: 1996, Das Fördergebietsgesetz, second edn, RWS Verlag Kommunikationsforum.

Vossius, O.: 1995, Sachenrechtsbereinigungsgesetz. Kommentar, C.H. Beck, München.

Yatchew, A.: 2003, Semiparametric Regression for the Applied Econometrician, Themes in Modern Econometrics, Cambridge University Press, Cambridge. 


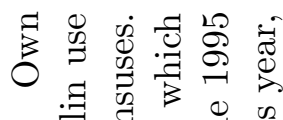

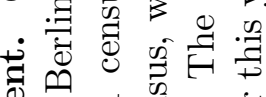

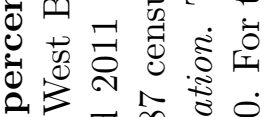

a

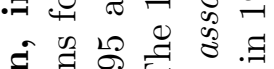

$\exists$ :

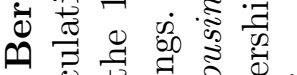

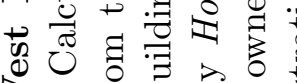

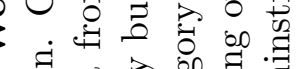

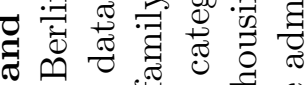

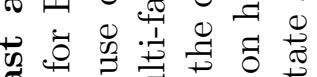

का का

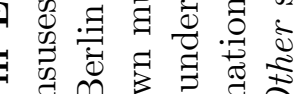

n

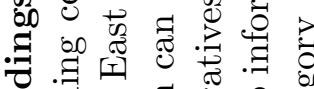

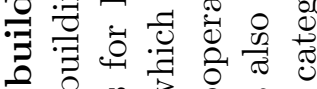

$=0$ w 300

프

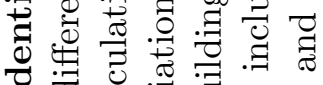

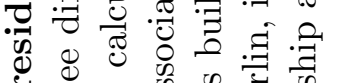

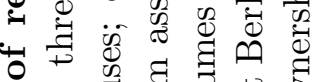

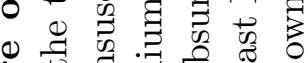

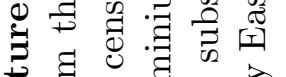

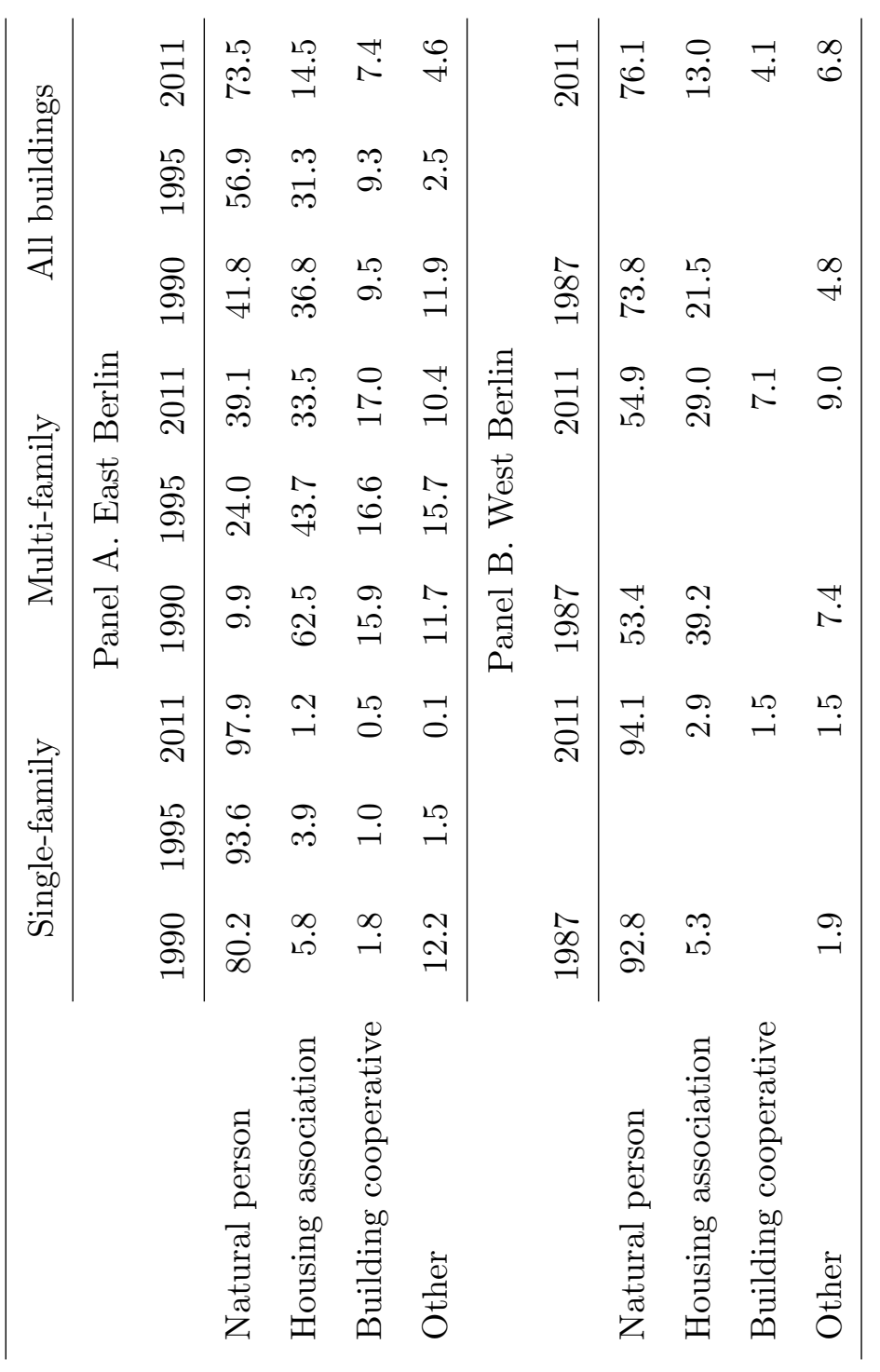

응 3

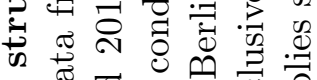

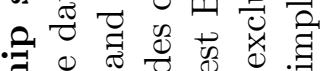

क

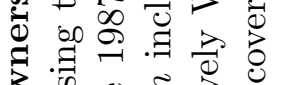

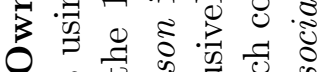

ㄱ.

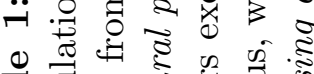

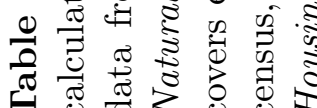

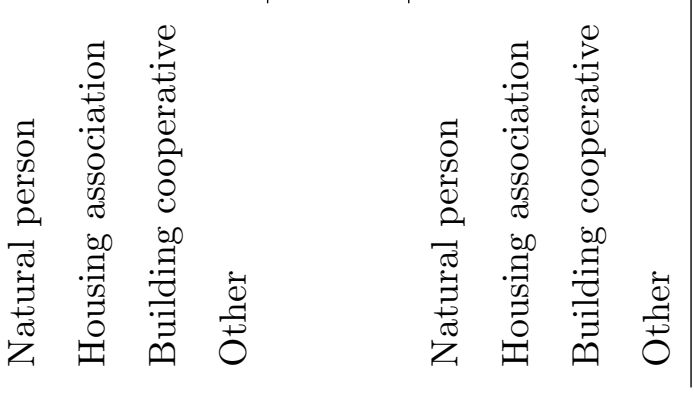


Table 2: Characteristics of the housing stock in Berlin, in percent. Own calculations using the three different building censuses for Berlin. Calculations for West Berlin use data from the 1987 and 2011 censuses; calculations for East Berlin use data from the 1995 and 2011 censuses. Columns of Building type and Building vintage each add to one hundred. Category Building vintage 1949-90 for West Berlin is based on the 1987 census and covers only vintages 1949-1987.

\begin{tabular}{lrrrr}
\hline & \multicolumn{2}{c}{ West } & \multicolumn{2}{c}{ East } \\
& 1987 & 2011 & 1995 & 2011 \\
\cline { 2 - 5 } Building vintage & & & & \\
before 1919 & 19.2 & 16.4 & 23.2 & 13.7 \\
$1919-48$ & 29.7 & 25.6 & 38.3 & 25.8 \\
$1949-90$ & 51.1 & 47.4 & 33.0 & 27.9 \\
1991-95 & & 2.9 & 5.5 & 5.6 \\
after 1995 & & 7.7 & & 27.0 \\
Building type & & & & \\
Single-family & 52.4 & 54.2 & 47.1 & 58.4 \\
Multi-family & 47.6 & 45.8 & 52.9 & 41.6 \\
Building damages & & & & \\
single-family minor & & & 50.3 & \\
single-family major & & & 15.0 & \\
multi-family minor & & & 39.1 & \\
multi-family major & & & 40.5 & \\
\hline
\end{tabular}


Table 3: Characteristics of dwellings in Berlin, in percent. Own calculations using the three different building censuses for Berlin. Calculations for West Berlin use data from the 1987 and 2011 censuses; calculations for East Berlin use data from the 1995 and 2011 censuses. Columns in In buildings with vintage each add to one hundred. Category 194990 for West Berlin is based on the 1987 census and covers only vintages 1949-1987.

\begin{tabular}{crrrr}
\hline & \multicolumn{2}{c}{ West } & \multicolumn{2}{c}{ East } \\
& 1987 & 2011 & 1995 & 2011 \\
\cline { 2 - 5 } In buildings with vintage & & & \\
before 1919 & 31.3 & 29.4 & 28.0 & 23.7 \\
$1919-48$ & 16.8 & 15.5 & 17.1 & 14.1 \\
$1949-90$ & 51.9 & 49.0 & 51.6 & 47.0 \\
$1991-95$ & & 2.5 & 3.3 & 3.0 \\
after 1995 & & 3.7 & & 12.2 \\
In building with & & & & \\
minor damages & & & 38.0 & \\
major damages & & & 39.3 & \\
\hline
\end{tabular}


Table 4: Time until land plot's first market transaction after reunification. Reports OLS estimates of Eq. 1. Number of observations is 11,984 . District dummies and constant are included but not reported. Heteroscedasticity robust standard errors are reported in brackets. ${ }^{* * *} 0.1 \%$-level ${ }^{* *} 1 \%$-level ${ }^{*} 5 \%$-level.

\begin{tabular}{lcr} 
Dep. var.: Log time until first transaction \\
\hline Assembly & $0.204^{* * *}$ & {$[0.030]$} \\
Inheritance & $-0.112^{*}$ & {$[0.051]$} \\
Contractual & $0.042^{* *}$ & {$[0.016]$} \\
Merge & $0.269^{* * *}$ & {$[0.020]$} \\
Back & $0.189^{* * *}$ & {$[0.012]$} \\
Contamination & $0.328^{* * *}$ & {$[0.050]$} \\
Heritage asset & $0.340^{* * *}$ & {$[0.059]$} \\
Commercial use & $-1.061^{* * *}$ & {$[0.017]$} \\
Waterfront & $0.108^{* *}$ & {$[0.044]$} \\
Private-to-public & $0.184^{* * *}$ & {$[0.044]$} \\
Public-to-private & $0.372^{* * *}$ & {$[0.021]$} \\
Public-to-public & $0.243^{* *}$ & {$[0.089]$} \\
\hline$R^{2}$ & 0.462 & \\
\hline
\end{tabular}


Table 5: Transaction propensity after reunification of singlefamily houses constructed during the GDR. Reports marginal effects from ML estimates of Eq. 2. Marginal effects are evaluated at sample means of explanatory variables. Uses transactions of single-family houses constructed before 3 October 1990. Number of observations is 18,376. Time-dummies, district-dummies and constant are included, but not reported. Heteroscedasticity robust standard errors are reported in brackets. Standard errors are computed using the delta method. ${ }^{* * *} 0.1 \%$-level **1\%-level *5\%-level.

\begin{tabular}{|c|c|c|c|c|}
\hline \multirow[b]{2}{*}{ East } & \multicolumn{2}{|c|}{ (1) } & \multicolumn{2}{|c|}{ (2) } \\
\hline & $-0.865^{* * *}$ & {$[0.057]$} & $-0.690^{* * *}$ & {$[0.050]$} \\
\hline East $\times$ After & $0.142^{* * *}$ & {$[0.024]$} & $0.113^{* * *}$ & {$[0.022]$} \\
\hline Floor to area ratio & & & $0.283^{* * *}$ & {$[0.030]$} \\
\hline Attic & & & $-0.203^{* * *}$ & {$[0.014]$} \\
\hline Flat roof & & & $0.429^{* * *}$ & {$[0.010]$} \\
\hline 2-3 Storeys & & & $-0.172^{* * *}$ & {$[0.008]$} \\
\hline Waterfront & & & -0.032 & {$[0.033]$} \\
\hline \multicolumn{5}{|l|}{ Building type } \\
\hline Semi-detached & & & $-0.039^{* * *}$ & {$[0.008]$} \\
\hline Row house & & & $-0.066^{* * *}$ & {$[0.012]$} \\
\hline End row house & & & $0.073^{* * *}$ & {$[0.015]$} \\
\hline \multicolumn{5}{|l|}{ State of repair } \\
\hline Poor & & & $-0.125^{* * *}$ & {$[0.013]$} \\
\hline Excellent & & & $0.217^{* * *}$ & {$[0.009]$} \\
\hline \multicolumn{5}{|l|}{ Non-private } \\
\hline Buyer & & & $-0.049^{*}$ & {$[0.021]$} \\
\hline Seller & & & $-0.158^{* * *}$ & {$[0.012]$} \\
\hline Pseudo $R^{2}$ & 0.063 & & 0.226 & \\
\hline
\end{tabular}


Table 6: Oaxaca-Blinder decomposition of building value. Decomposition uses OLS estimates of Eq. A3. Regression is fitted using only building values for arms-length transactions. Heteroscedasticity robust standard errors are reported in brackets. Standard errors for the decomposition are computed according to the approximation in Oaxaca and Ransom (1998). Significant at ${ }^{* * *} 0.1 \%$-level ${ }^{* *} 1 \%$-level ${ }^{*} 5 \%$-level.

Panel A. 1991-1999 $(N=7,543)$

Differential

West Berlin $\quad 11.769^{* * *} \quad[0.010]$

East Berlin $\quad 11.142^{* * *} \quad[0.021]$

Difference $\quad 0.627^{* * *} \quad[0.023]$

Decomposition

Characteristics $\quad 0.395^{* * *} \quad[0.025]$

Coefficients $\quad 0.233^{* * *} \quad[0.035]$

Panel B. 2000-2008 $(N=12,498)$

Differential

West Berlin $\quad 11.580^{* * *} \quad[0.008]$

East Berlin $\quad 11.480^{* * *} \quad[0.010]$

Difference $\quad 0.099^{* * *} \quad[0.012]$

Decomposition

Characteristics $\quad 0.138^{* * *} \quad[0.016]$

$\begin{array}{lll}\text { Coefficients } & -0.039 & {[0.020}\end{array}$ 
Table A1: Transactions of land plots and single-family houses in Berlin. Year 1990 covers only the period starting with the German reunification on 3 October 1990.

\begin{tabular}{rrrrr}
\hline & \multicolumn{2}{c}{ Plots } & \multicolumn{2}{c}{ Houses } \\
\cline { 2 - 5 } & East & West & East & West \\
\hline 1990 & 38 & 900 & 5 & 669 \\
1991 & 780 & 812 & 119 & 623 \\
1992 & 1,407 & 621 & 184 & 633 \\
1993 & 2,196 & 585 & 317 & 863 \\
1994 & 2,436 & 549 & 201 & 674 \\
1995 & 2,028 & 432 & 160 & 687 \\
1996 & 2,009 & 455 & 242 & 707 \\
1997 & 1,801 & 430 & 255 & 680 \\
1998 & 1,953 & 546 & 315 & 767 \\
1999 & 1,967 & 640 & 350 & 801 \\
2000 & 1,724 & 555 & 451 & 789 \\
2001 & 1,327 & 418 & 484 & 838 \\
2002 & 1,436 & 480 & 460 & 905 \\
2003 & 1,633 & 450 & 431 & 980 \\
2004 & 1,648 & 482 & 468 & 942 \\
2005 & 1,973 & 647 & 618 & 1,123 \\
2006 & 1,725 & 587 & 427 & 1,015 \\
2007 & 1,550 & 528 & 476 & 1,128 \\
2008 & 1,500 & 500 & 597 & 1,160 \\
\hline & & & &
\end{tabular}


Table A2: Building type and repair of transacted single-family houses, in percent. Expressed relatively to all transactions in the respective part of Berlin and for the given period.

\begin{tabular}{lrrrr}
\hline & \multicolumn{2}{c}{ East Berlin } & \multicolumn{2}{c}{ West Berlin } \\
& $1991-99$ & $2000-08$ & $1991-99$ & $2000-08$ \\
\cline { 2 - 5 } Building type & & & & \\
detached & 70.79 & 54.35 & 54.20 & 51.02 \\
semi-detached & 23.52 & 32.32 & 26.74 & 29.52 \\
terraced & 5.69 & 13.33 & 19.05 & 19.45 \\
State of repair & & & & \\
excellent & 18.08 & 46.15 & 30.86 & 26.35 \\
fair & 58.87 & 37.42 & 67.18 & 71.65 \\
poor & 23.05 & 16.43 & 1.96 & 2.00 \\
\hline
\end{tabular}




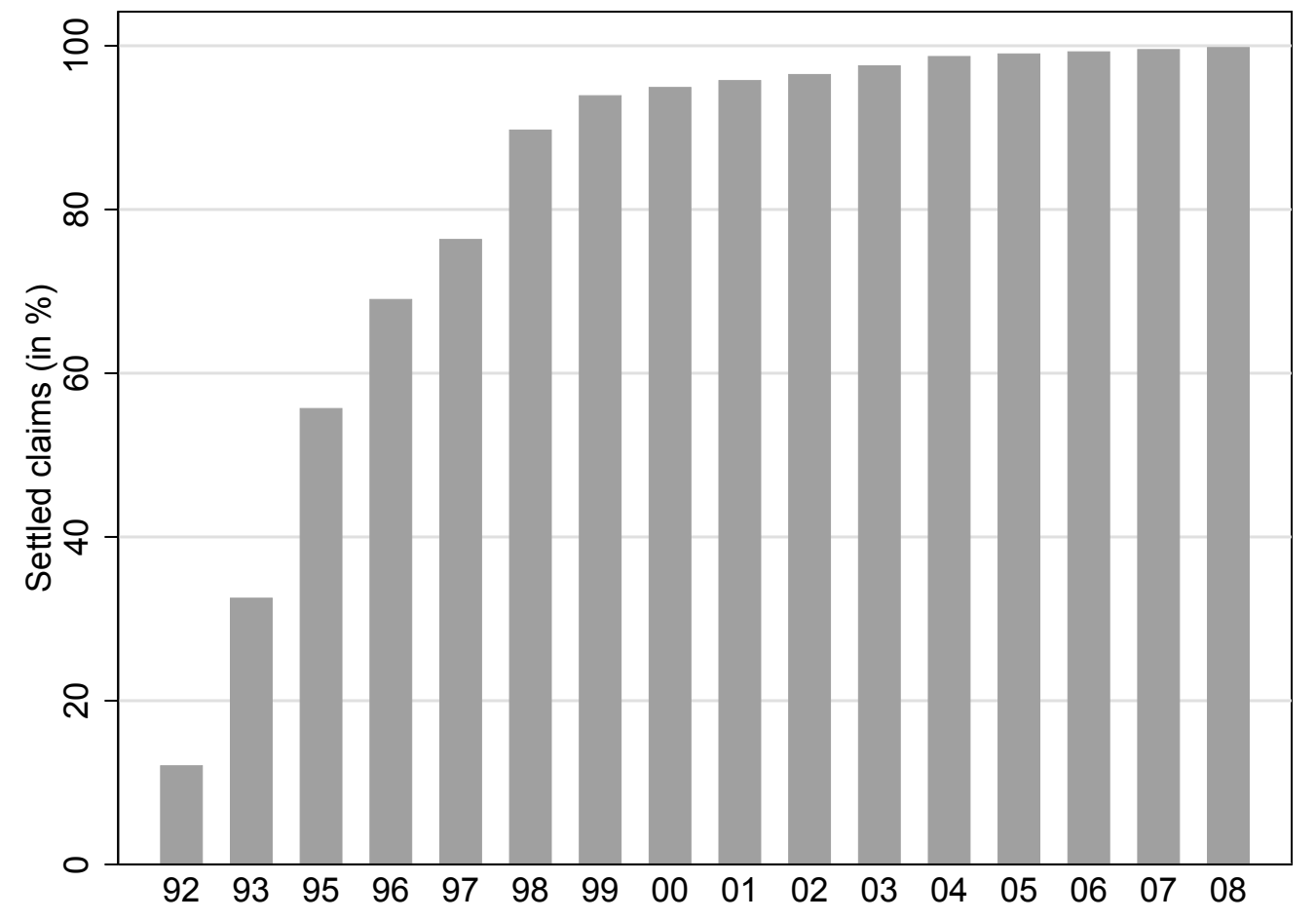

Figure 1: Open and settled claims about restitution of land and buildings in East Berlin. Shows percentage of settled claims. Own calculations based on annual reports 1992-2008 from the Federal Office for Central Services and Unresolved Property Issues. 


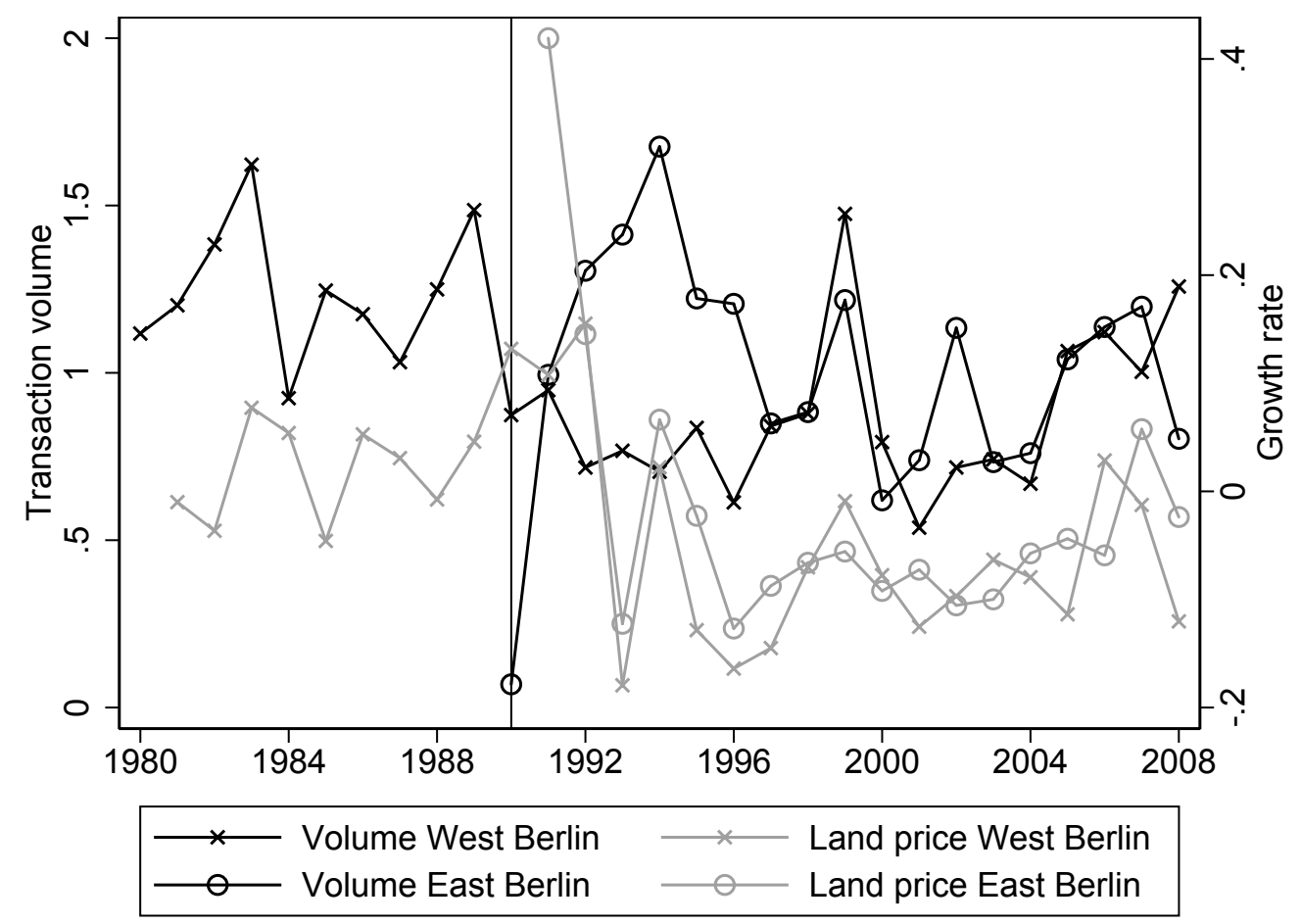

Figure 2: Relative transaction volume and land price growth rate. Left axis shows the volume of transacted land in sqm relative to its long-run average. Volume is computed using all transactions. Right axis measures growth rate of land price per sqm. Growth rates are computed from quality-controlled price indices. Indices are computed from real (year 2010) transaction prices of arms-length transactions. 

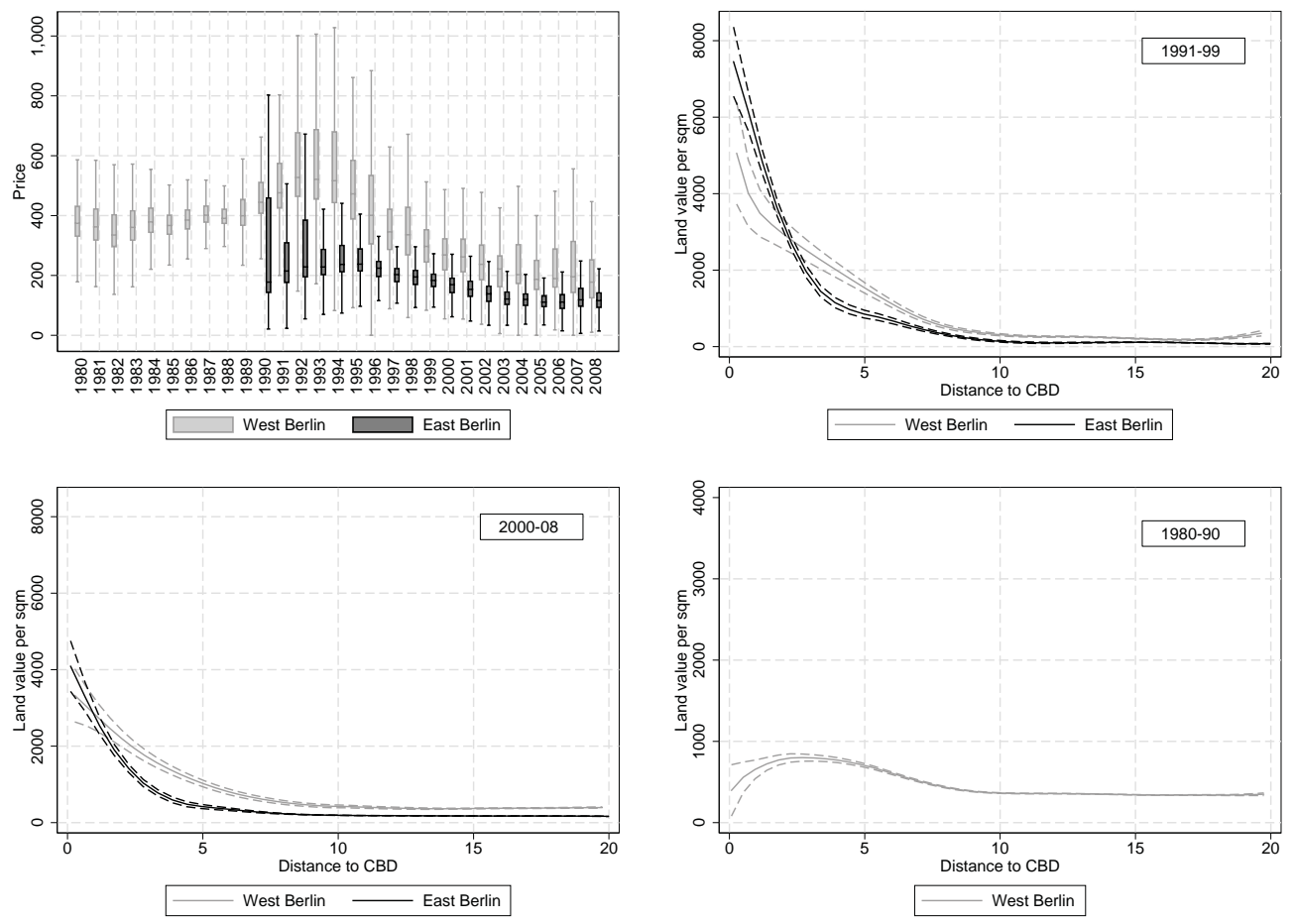

Figure 3: Land price distributions and gradients. Top-left panel shows cross-sectional land price distributions. Lower (upper) hinge of box corresponds to 25 th $(75$ th) percentile. Line in the middle is the median. Top-right to bottom-right panels show local polynomial estimates of land price gradients. Dotted lines are $95 \%$ point-wise confidence bands. The CBD is the Potsdamer Platz; distance is measured in km. All panels use real (year 2010) price per sqm of arms-length transactions in respective period. Estimation period for bottom-right panel is truncated at 3 October 1990. 

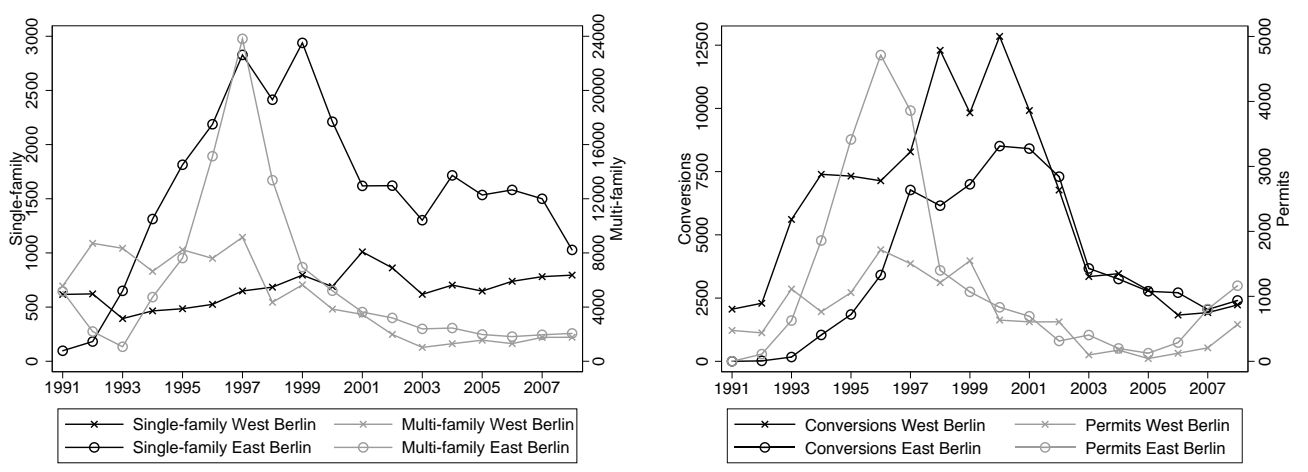

Figure 4: Completion of residential dwellings and conversions and permits for condominiums. Left panel shows completions of new dwellings. Single-family dwellings are in buildings with up to two dwellings, multi-family dwellings are in buildings with more than two dwellings. Data from 2001 onwards without the districts of FriedrichshainKreuzberg and Mitte-Tiergarten. Right panel shows conversions and building permits for condominiums. Conversions refer to the number of dwellings in existing buildings that are converted into condominiums. Permits refer to the number of permits for condominiums in newly constructed buildings. 


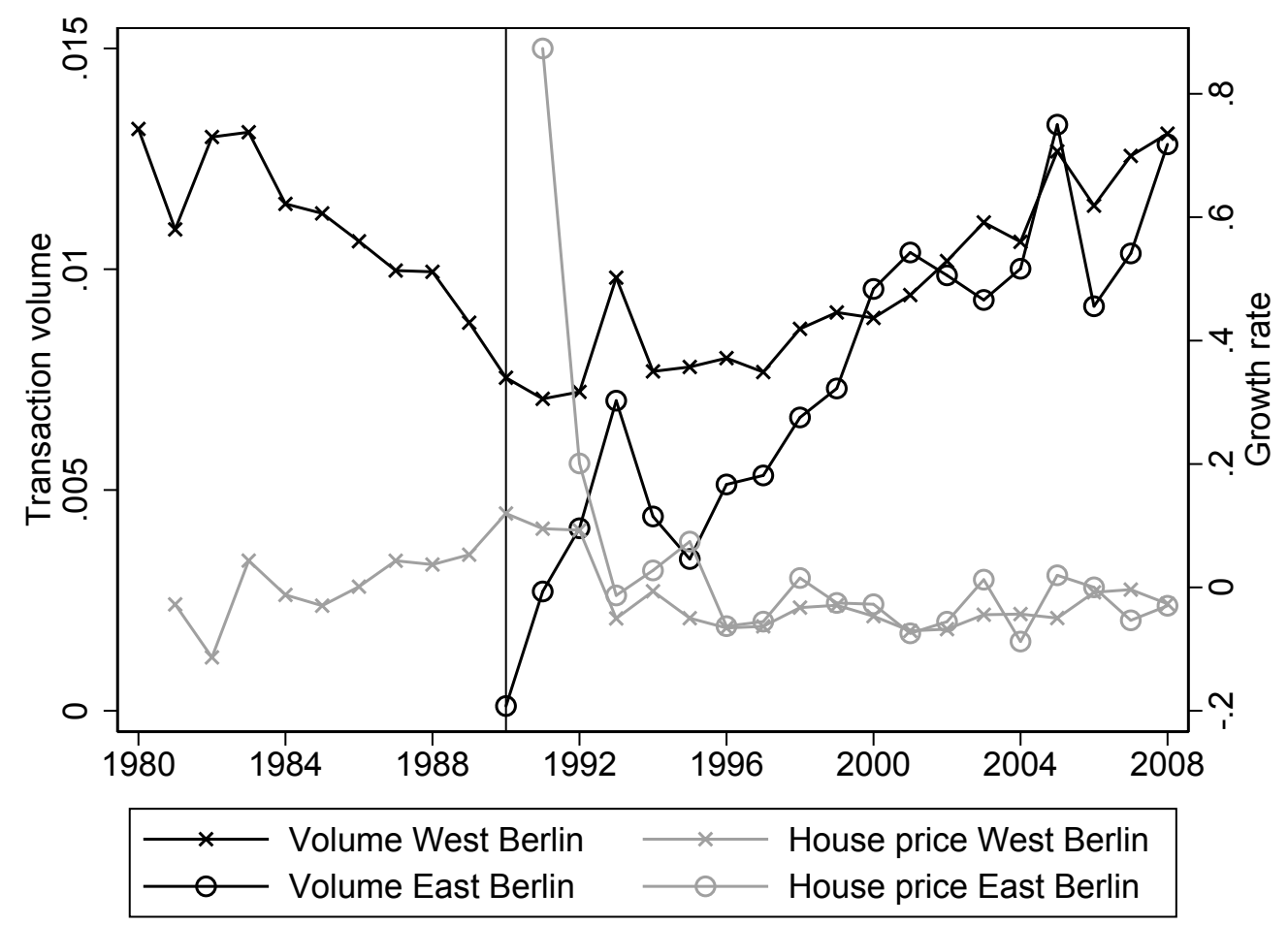

Figure 5: Relative transaction volume and house price growth rate. Left axis shows transaction volume relative to single-family housing stock. Volume is computed using all observed transactions. Housing stock is calculated from 1987 and 1995 building censuses and completions of new single-family houses. Right axis measures growth rate of single-family house price. Growth rates are computed from quality-controlled price indices. Indices are computed from real (year 2010) transaction prices of arms-length transactions. 

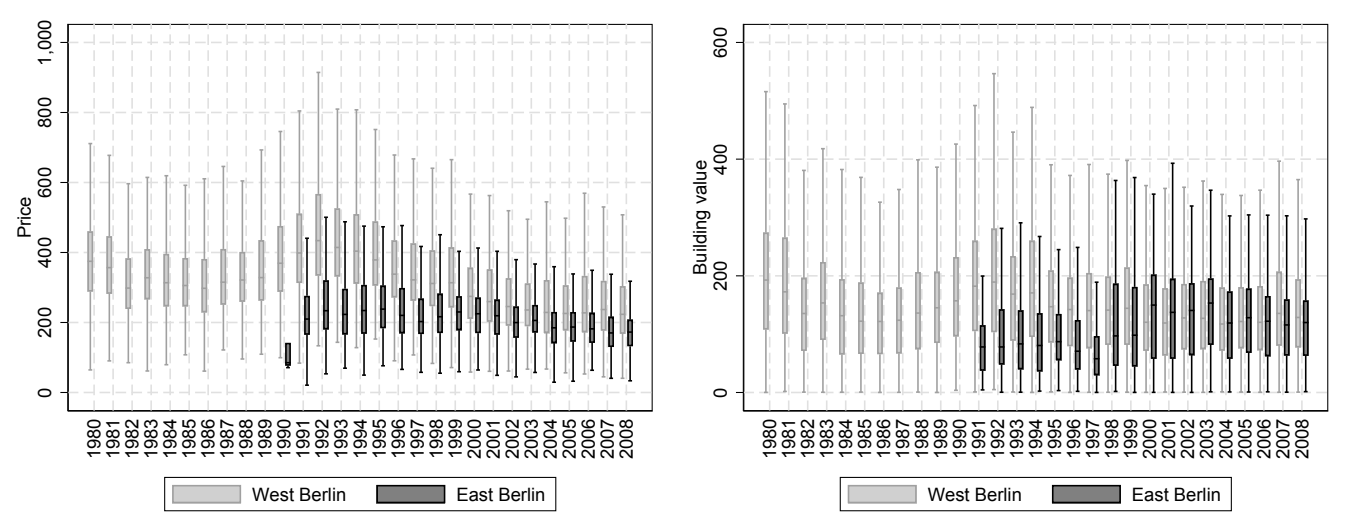

Figure 6: Distributions of house prices and building values. Uses arms-lengths transactions of single-family houses. House price and building value are in real (year 2010) Euros. In '000 units. Building value is transaction price net of assessed land value. Lower (upper) hinge of box corresponds to 25 th $(75$ th) percentile. Middle line is the median. 


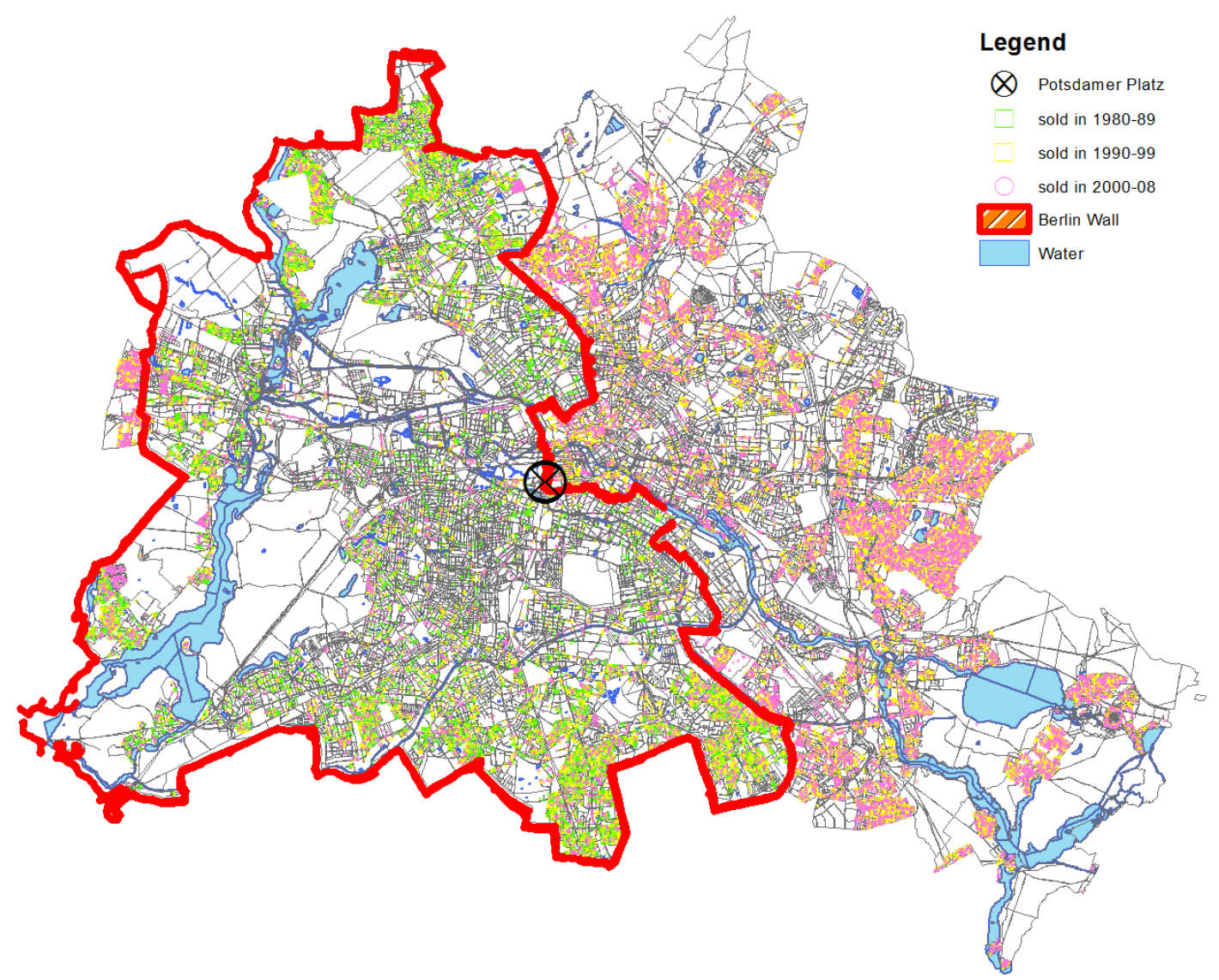

Figure A1: Location of transacted plots of land. Berlin covers an area of $891 \mathrm{sqkm}$, the maximal extension in west-to-east direction is 45 $\mathrm{km}$. Thick (red) line represents the Berlin Wall, which entirely surrounded West Berlin. Circle indicates location of Potsdamer Platz. Thin black lines represent streets and street blocks. Solid grey (blue) areas are rivers and lakes. White areas are forests, other green spaces, and non-developed areas. Total number of observations is 52,929 . 


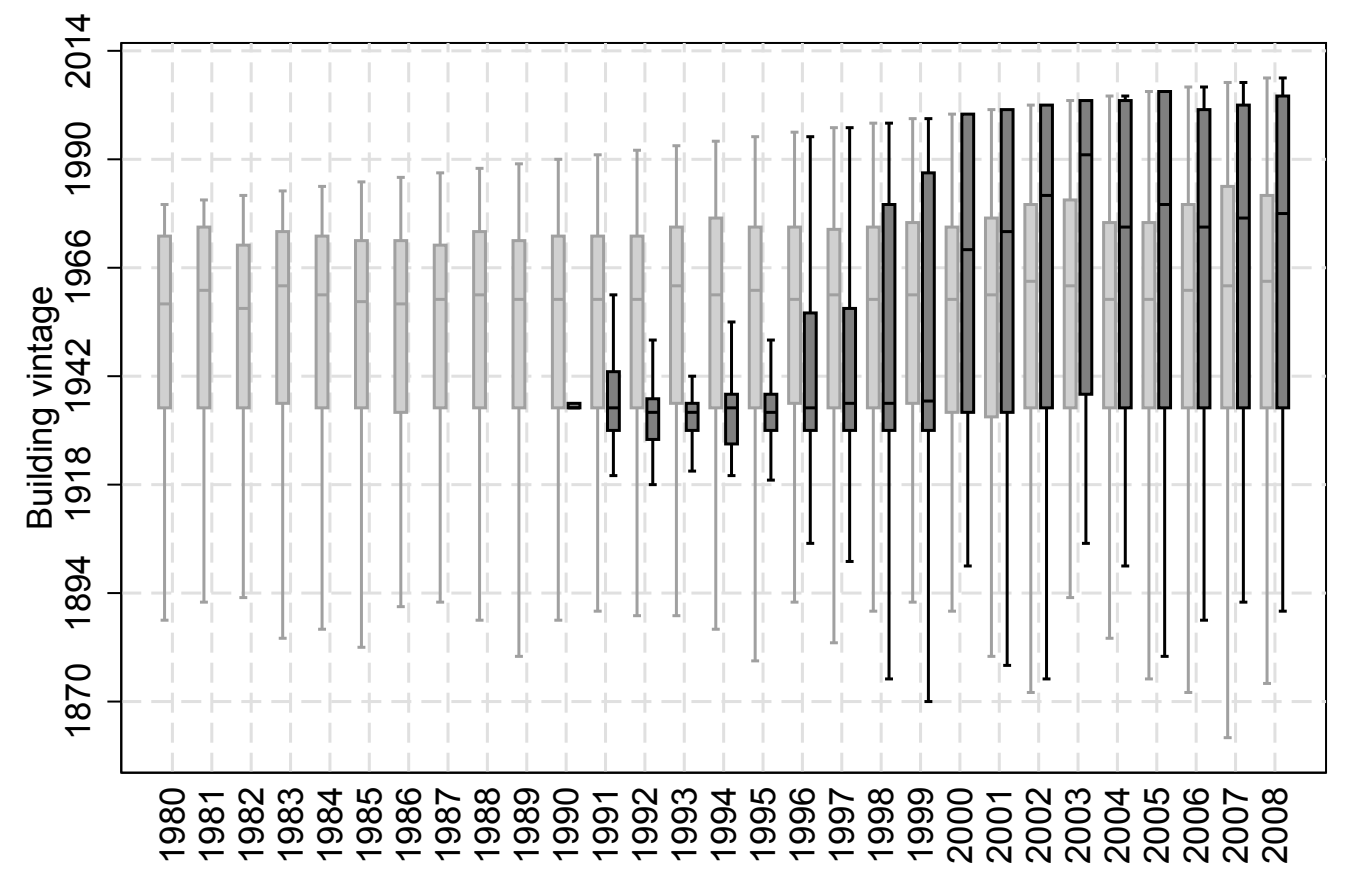

\section{West Berlin $\square$ East Berlin}

Figure A2: Cross-sectional building vintage distributions (19802008). Uses arms-lengths transactions of single-family houses. Building vintage is measured by year of construction. Lower (upper) hinge of box corresponds to 25 th $(75$ th $)$ percentile. Middle line is the median. 

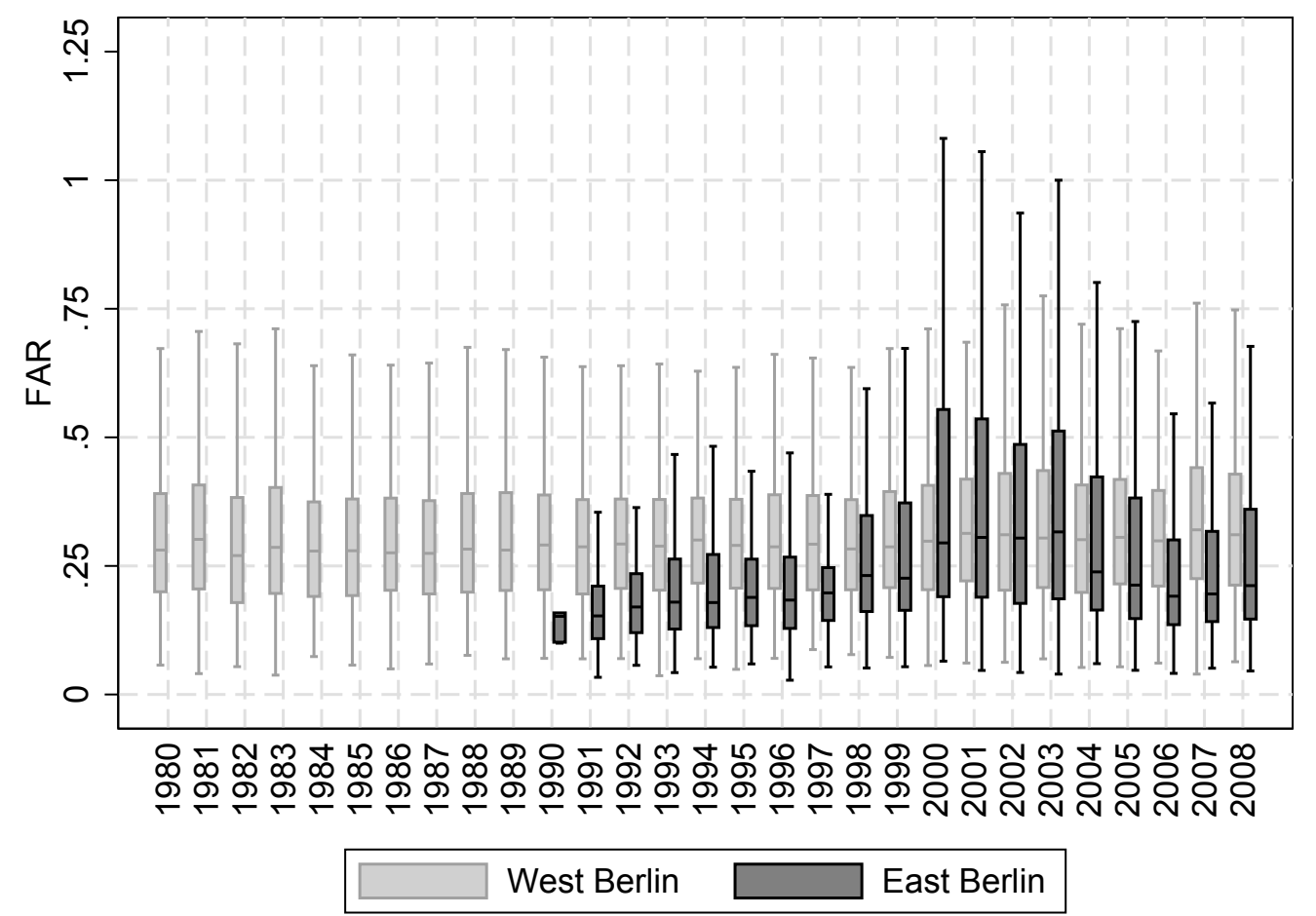

Figure A3: Cross-sectional floor-to-area ratio distributions (1980-2008). Uses arms-lengths transactions of single-family houses. Lower (upper) hinge of box corresponds to 25th (75th) percentile. Middle line is the median. 